\title{
Interaction of $\mathrm{H}_{2} \mathrm{O}$ and $\mathrm{NO}_{2}$ with $\mathrm{BaY}$ Faujasite: Complex Contraction/Expansion Behavior of the Zeolite Unit Cell
}

\author{
Xianqin Wang, ${ }^{\dagger}$ Jonathan C. Hanson, ${ }^{\dagger}$ János Szanyi, ${ }^{\dagger}$ and José A. Rodriguez ${ }^{* \dagger}$ \\ Chemistry Department, Brookhaven National Laboratory, Upton, New York 11973, and \\ Chemical Sciences Division, Pacific Northwest National Laboratory, Richland, Washington 99352
}

Received: August 19, 2004; In Final Form: September 16, 2004

\begin{abstract}
In situ time-resolved X-ray diffraction in combination with the Rietveld method was used to study the contraction/expansion behavior of a $\mathrm{BaY}$ faujasite zeolite during dehydration and $\mathrm{NO}_{2}$ adsorption/desorption reactions. The adsorption of water and $\mathrm{NO}_{2}$ molecules induced a significant contraction of the zeolite unit cell. The unexpected contraction of the unit cell was closely related to the amount of water and $\mathrm{NO}_{x}$ species $\left(\mathrm{NO}^{+}, \mathrm{NO}_{2}, \mathrm{NO}_{3}{ }^{-}\right)$inside the framework. The reaction $\mathrm{H}_{2} \mathrm{O}+\mathrm{NO}_{2} \rightarrow \mathrm{NO}_{3}{ }^{-}+\mathrm{H}^{+}$had a substantial effect on the structural properties of the $\mathrm{BaY}$ system. The $\mathrm{NO}_{3}{ }^{-}$groups produced a shift in the position of the $\mathrm{Ba}$ cations and a reduction in the zeolite unit cell.
\end{abstract}

\section{Introduction}

Zeolites possess unique features as gas adsorbents, gas separators, chemical sensors and catalysts. ${ }^{1}$ Their structures are particularly sensitive to extraframework cations, temperature, pressure and guest polar molecules. ${ }^{2-7}$ The unit cell change obtained from the Rietveld refinement of the X-ray diffraction data has been used to probe structural changes of zeolites in many studies. These changes can arise from the difference in the amount and/or position of extraframework atoms and the intrinsic mechanism of negative thermal expansion. A recent striking example of the effect of extraframework atoms on volume was the discovery that additional water can bind to $\mathrm{K}-\mathrm{GaSi}-$ naturolite at $1.2 \mathrm{GPa}$ and result in about $1 \%$ increase in cell volume. ${ }^{8}$ During the thermal dehydration of the zeolites HZSM, ${ }^{9}$ Rho, ${ }^{10}$ and $\mathrm{A}^{11}$ the cell volume was found to decrease, whereas for $\mathrm{Cs}(\mathrm{Na})-\mathrm{Y}$ zeolite it was found to increase between 100 and $215^{\circ} \mathrm{C} .5^{5}$ On the other hand, an intrinsic negative thermal expansion has been observed in several zeolites when the composition of the unit cell remains constant. ${ }^{12,13}$ For fundamental and practical reasons, it is important to establish how the chemical transformation of an adsorbent can change the unit cell of a zeolite. ${ }^{2-7}$

The destruction of $\mathrm{NO}_{x}$ species formed during the combustion of fuels in automobiles, factories, and power plants has become a very important part of controlling environmental pollution. ${ }^{14}$ $\mathrm{BaY}$ faujasite zeolites have been reported to be very promising catalysts for the nonthermal plasma-assisted catalytic reduction of $\mathrm{NO}_{x}$ species. ${ }^{15}$ Water is an important guest molecule in the pore system of natural and synthetic zeolites. The adsorptive and catalytic properties of zeolites are also strongly affected by their water content. 5,16 Cations seek the most energetically stable positions and these positions play an important role in catalytic activity. Therefore, the positions of the extraframework cations in the $\mathrm{BaY}$ structure during dehydration and $\mathrm{NO}_{2}$ adsorption/reaction are critical to understand the SCR (selective catalytic reduction) properties of these materials. ${ }^{5,15}$ In the present work, the complex behavior of the BaY unit cell during

\footnotetext{
$\dagger$ Brookhaven National Laboratory.

$\doteqdot$ Pacific Northwest National Laboratory.
}

dehydration and interaction with $\mathrm{NO}_{2}$ was investigated by in situ time-resolved X-ray diffraction.

\section{Experimental and Data Refinement}

A BaY faujasite zeolite with a $\mathrm{Si} / \mathrm{Al}$ ratio of $\sim 2.6$ was prepared from a $\mathrm{NaY}$ zeolite obtained from Zeolyst International (CBV 100) following the procedure described in ref 15 . The dehydration process was followed in time-resolved X-ray diffraction experiments carried out at the beamline X7B of the National Synchrotron Light Source (NSLS), Brookhaven National Laboratory. The details of the experimental setup have been described elsewhere. ${ }^{17} \mathrm{~A}$ small amount of sample $(\sim 0.005$ g) was dehydrated by slowly heating from 25 to $350{ }^{\circ} \mathrm{C}$ and a mechanical pump was used to remove the desorbed water (pressure $\sim 1$ mTorr). $\mathrm{NO}_{2}(99.99 \%$ purity) was dosed over both hydrated and dehydrated $\mathrm{BaY}$ samples. The $\mathrm{NO}_{2}$ was dosed to the dehydrated samples after heating them to $350{ }^{\circ} \mathrm{C}$ and cooling to room temperature. In the case of $\mathrm{NO}_{2}$ dosing over the hydrated samples, exposure to the gas took place without preheating the samples to $350^{\circ} \mathrm{C}$. The $\mathrm{NO}_{2}$ dosed samples were then heated to high temperatures to induce transformation and desorption of $\mathrm{NO}_{x}$ species. Time-resolved X-ray diffraction (TRXRD) data were collected during all of these processes. ${ }^{18,19}$

Rietveld refinements were performed with the program GSAS with the EXPGUI graphical interface. ${ }^{20}$ Atomic coordinates for the framework of dehydrated $\mathrm{BaY}$ obtained from previous refinements were used as the starting model. ${ }^{21}$ The $\mathrm{T}-\mathrm{O}(\mathrm{T}$ : $\mathrm{Si}$ or $\mathrm{Al}$ ) distances and angles were constrained. The background curve was fitted with a Chebyshev polynomial with 30 coefficients. The diffraction peak shape was modeled with a pseudoVoigt function with three Gaussian and two Lorentzian linebroadening terms. One scale factor and the unit cell parameters were allowed to vary for all patterns. Occupancy factors and isotropic displacement coefficients of the extraframework species and the thermal parameters were refined at the same time. However, the thermal parameters were constrained for all the atoms with the same structural role, for instance, the thermal parameters for the framework oxygen atoms were constrained to be the same, and as were the thermal parameters for all the extraframework cations. 


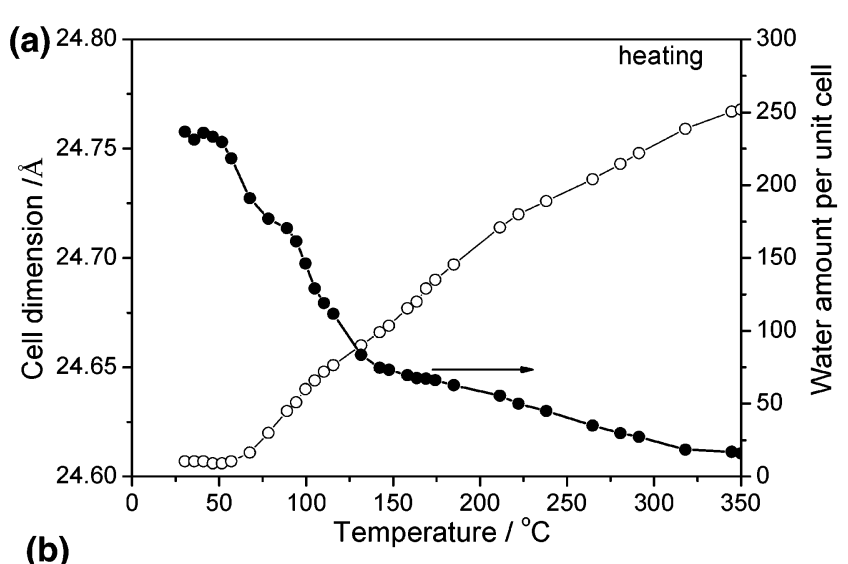

(b)

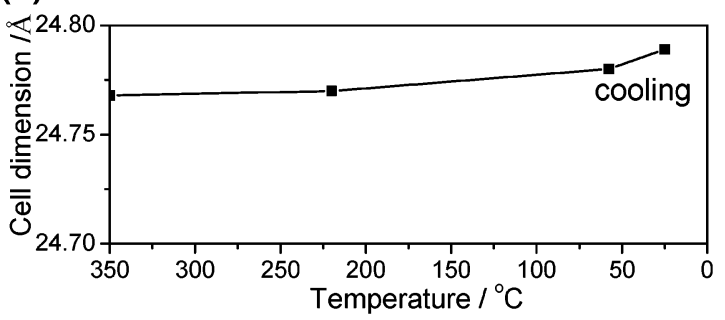

Figure 1. (a) Cell dimension (open symbols) and water amount per unit cell (solid symbols) as a function of temperature for the BaY faujasite dehydration. (b) Cell dimension as a function of temperature for the cooling of the $\mathrm{BaY}$ faujasite from $350{ }^{\circ} \mathrm{C}$ to room temperature after dehydration.

\section{Results and Discussions}

A. Dehydration of BaY Zeolite. The TR-XRD patterns for the dehydration process of a $\mathrm{BaY}$ zeolite were similar to those reported for the dehydration of a NaY zeolite ${ }^{22}$ and are not shown here. Figure 1a shows the cell dimension and the amount of water per unit cell as a function of temperature during the dehydration process. Several slopes are seen in the curve for the variation in the cell dimension, and the breaking points are at temperatures of 50,110 , and $220^{\circ} \mathrm{C}$. A comparison with the water removal curve indicates that the cell expansion was closely related to the water removal rate. At temperatures below 50 ${ }^{\circ} \mathrm{C}$, the unit cell decreased slightly with a very small negative thermal expansion coefficient of $-5.63 \times 10^{-5} \AA /{ }^{\circ} \mathrm{C}$. At this stage, the amount of water was nearly constant with a value of 236 water molecules per unit cell. At temperatures between 50 and $110^{\circ} \mathrm{C}$, the unit cell expanded quickly with a larger thermal expansion coefficient of $8.518 \times 10^{-4} \AA{ }^{\circ} \mathrm{C}$. During this stage, the amount of water in the sample decreased dramatically. This is consistent with the results for $\mathrm{Cs}(\mathrm{Na}) \mathrm{Y}^{5}$ where the cell unit parameter expanded during the removal of water at certain temperatures. Upon further heating, the unit cell expansion became slow with a thermal expansion coefficients of $6.59 \times$ $10^{-4} \AA /{ }^{\circ} \mathrm{C}$ at the temperatures between 110 and $220^{\circ} \mathrm{C}$, and $3.85 \times 10^{-4} \AA /{ }^{\circ} \mathrm{C}$ between 220 and $350{ }^{\circ} \mathrm{C}$. During the cooling of the sample to room temperature, the unit cell expanded (Figure 1b), demonstrating that the dehydrated BaY faujasite zeolite has a negative thermal expansion coefficient similar to that in NaY faujasite. ${ }^{22}$

The BaY unit cell parameters at room temperature before and after dehydration were 24.607 and $24.848 \AA$, respectively. This result implies that the unit cell contracted more than 0.24 $\AA$ for hydrated materials. The contraction of the BaY unit cell induced by water is due to strong interactions among water, the cations, and faujasite framework. ${ }^{22}$ A simplified model showing a possible mechanism for the interactions is presented in Figure 2. The model derived from the XRD analysis is a

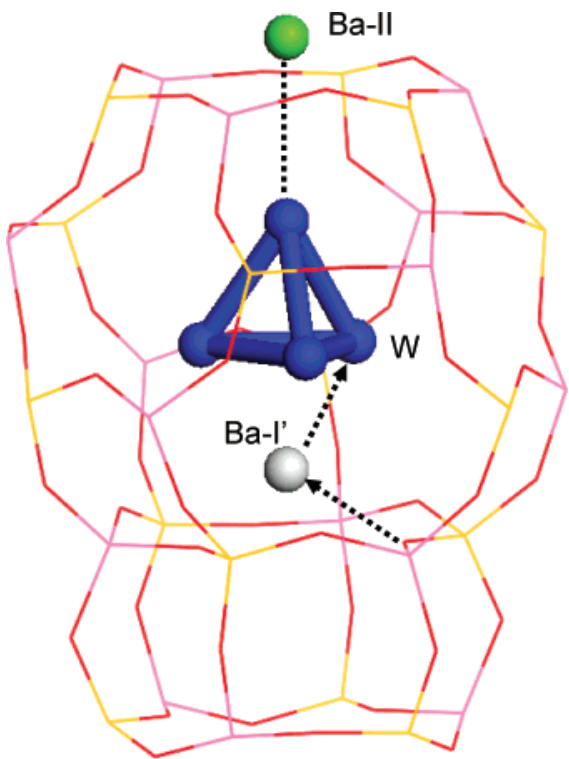

Figure 2. Simplified picture for the interactions among water, $\mathrm{Ba}$ cations, and the zeolite framework. A cluster structure of four $\mathrm{H}_{2} \mathrm{O}$ molecules is shown in the center of the sodalite cage.

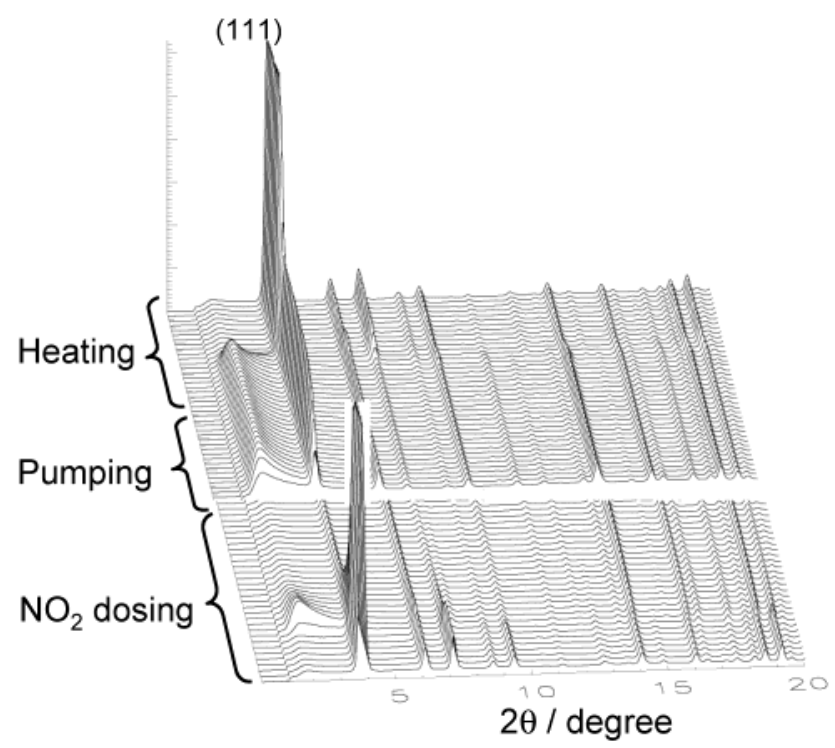

Figure 3. TR-XRD patterns for $\mathrm{NO}_{2}$ adsorption/desorption reactions over the dehydrated $\mathrm{BaY}$ sample. The sample was exposed to $\mathrm{NO}_{2}$ gases at $25^{\circ} \mathrm{C}$ after dehydration. The sample was saturated with $\mathrm{NO}_{2}$, the gases around the sample were pumped away for $2 \mathrm{~h}$, and then the sample was heated to $350{ }^{\circ} \mathrm{C}$ in $1 \mathrm{~h}$.

tetrahedral cluster of four water molecules inside the sodalite cage. ${ }^{22}$ When there is no water in the center of the sodalite cage, a common cation present in the zeolite cage, $\mathrm{BaI}^{\prime},{ }^{23}$ only interacts with the framework oxygen. However, once there is water in the sodalite cage, the interaction between water and the $\mathrm{BaI}^{\prime}$ cation becomes substantial, resulting in a force tending to pull the $\mathrm{BaI}^{\prime}$ cation toward the water, and thus the center of the sodalite cage. The framework oxygen atoms are also pulled toward the center of the sodalite cage because of the interaction with the BaI' cations. Thus, the sodalite cage shrinks. The unit cell of the faujasite decreases because it is composed of interconnected sodalite cages.

B. Interaction with $\mathrm{NO}_{2}$. A dehydrated $\mathrm{BaY}$ sample was exposed to $\mathrm{NO}_{2}$ at $25^{\circ} \mathrm{C}$ and heated to elevated temperatures. The time-resolved XRD patterns are shown in Figure 3. The intensity of the faujasite (111) peak decreased significantly after the adsorption of $\mathrm{NO}_{2}$ gas. During the dosing process, $\mathrm{NO}_{2}$ and 


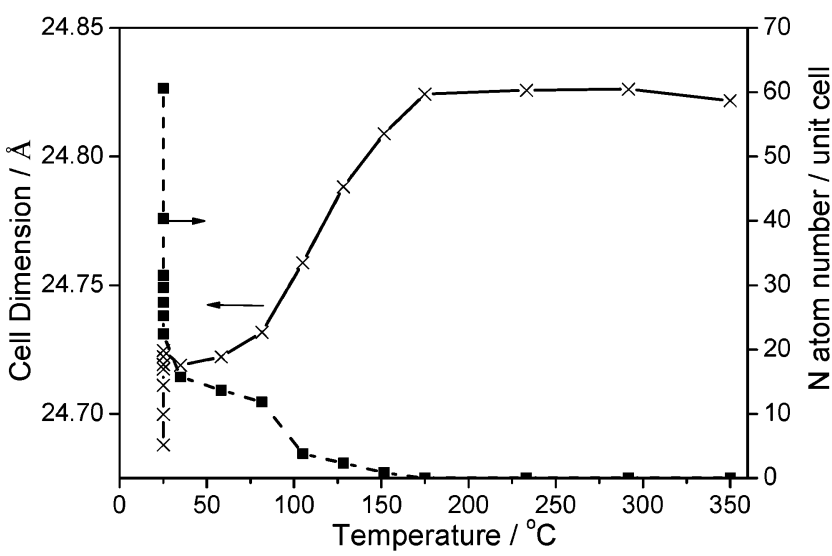

Figure 4. Cell dimension and the amount of $\mathrm{N}$-containing species per unit cell as a function of temperature refined from the data collected during $\mathrm{NO}_{2}$ pumping and heating processes in Figure 3.

its disproportionation products ${ }^{15,23}$ from the reaction $2 \mathrm{NO}_{2} \rightarrow$ $\mathrm{NO}_{3}{ }^{-}+\mathrm{NO}^{+}$chemisorbed on the Ba cations and/or framework of the $\mathrm{BaY}$ zeolite, resulting in the powder pattern changes displayed in Figure 3. The sample was considered to be saturated with $\mathrm{NO}_{2}$ on the basis of the fact that there were no longer observable changes in the XRD patterns. Then, the gases around the sample were pumped away. During pumping at $25^{\circ} \mathrm{C}$, some weakly adsorbed species $\left(\mathrm{NO}_{2} \text { and } \mathrm{NO}^{+}\right)^{15,23}$ were removed, and the intensity of the faujasite (111) peak increased a small amount. However, the value expected for the empty supercage was not reached until the sample was heated to a temperature of $350{ }^{\circ} \mathrm{C}$. Interestingly, there was a minor feature appearing at very low angle after the $\mathrm{NO}_{2}$ exposure. This feature is probably associated with aggregates of $\mathrm{NO}_{x}$ species formed outside the zeolite. ${ }^{23}$ The changes described above in the XRD patterns are related to the interaction of $\mathrm{NO}_{x}$ species with $\mathrm{Ba}$ cations and the zeolite framework.

The unit cell parameters from the initial and final XRD patterns in Figure 3 were determined to be 24.848 and 24.688 $\AA$, respectively. This indicates a unit cell contraction of more than $0.16 \AA$ resulted from the $\mathrm{NO}_{2}$ interaction with $\mathrm{BaY}$. This is somewhat smaller than the effect of water on the unit cell $(0.24 \AA)$. Figure 4 displays the unit cell changes and the total amount of $\mathrm{N}$-containing species $\left(\mathrm{NO}^{+}, \mathrm{NO}_{2}, \mathrm{NO}_{3}{ }^{-}\right)$per unit cell as a function of temperature. Right after $\mathrm{NO}_{2}$ exposure, there were $61 \mathrm{~N}$-containing species per unit cell. During pumping at $25^{\circ} \mathrm{C}$, the amount of $\mathrm{N}$-containing species per unit cell decreased while the unit cell expanded. After this process, only $22 \mathrm{~N}$-containing species were left in a unit cell of the zeolite. With the increase of the temperature to $100{ }^{\circ} \mathrm{C}$, most of the $\mathrm{NO}_{x}$ species were removed. However, a fraction of them remained until the temperature reached $175{ }^{\circ} \mathrm{C}$. The $\mathrm{N}$ containing species were distributed at different positions in the framework. ${ }^{23 a}$ For instance, $\mathrm{NO}_{3}{ }^{-}$located on top of site II and interacted with BaII cations. Obviously, the ratio of $\mathrm{NO}_{3}{ }^{-}$anions to BaII cations changed during these experiments. After pumping, the ratio was close to 1 and then decreased with heating. ${ }^{23 a}$ The unit cell changes were closely related to the amount of $\mathrm{N}$-containing species in the sample, similar to the case of water as was discussed above.

$\mathrm{NO}_{2}$ was also dosed over a hydrated $\mathrm{BaY}$ sample containing 236 water molecules per unit cell, followed by heating from 25 to $350{ }^{\circ} \mathrm{C} . \mathrm{NO}_{2}$ and $\mathrm{NO}_{3}{ }^{-}$groups (formed by reaction with water or disproportionation of $\mathrm{NO}_{2}$ ) were present inside the cages of the zeolite. ${ }^{15,23}$ Owing to the reaction $\mathrm{H}_{2} \mathrm{O}+\mathrm{NO}_{2} \rightarrow \mathrm{NO}_{3}{ }^{-}+$ $\mathrm{H}^{+}$, around $120 \mathrm{~N}$-containing species per unit cell were detected

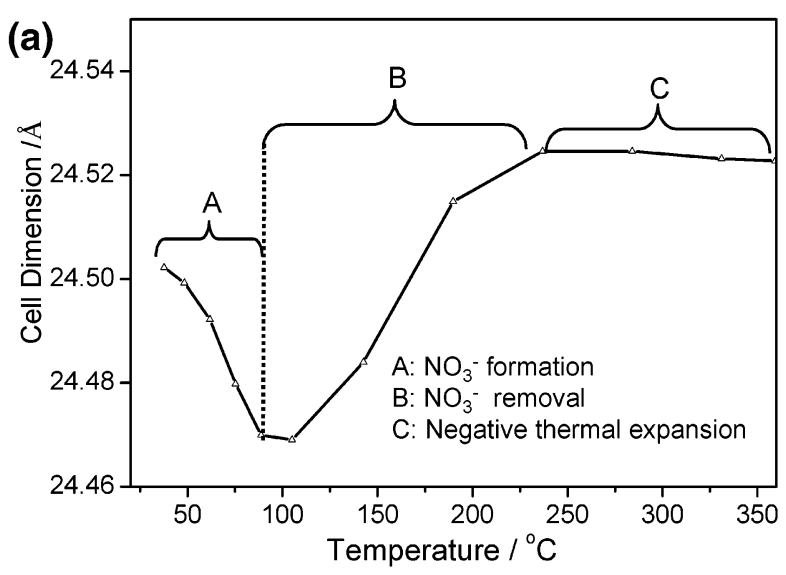

(b)

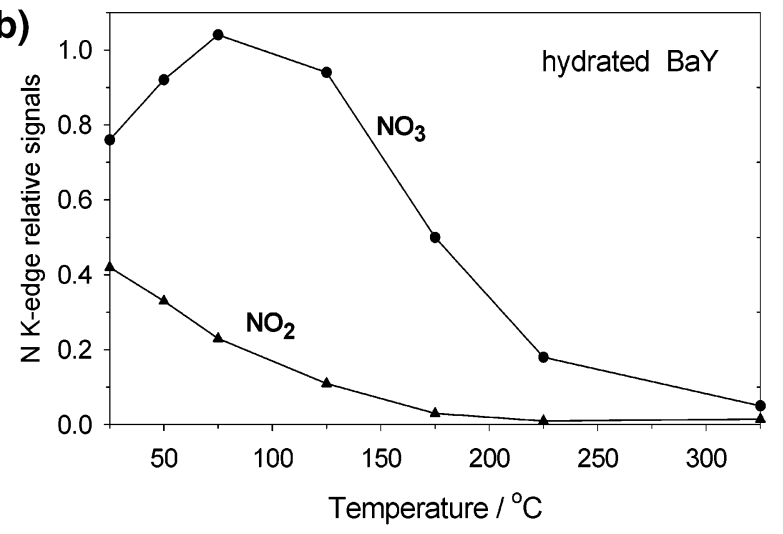

Figure 5. (a) Cell dimension as a function of temperature refined from the XRD data collected after heating a hydrated $\mathrm{BaY}$ sample exposed to $\mathrm{NO}_{2}$. (b) Relative amount of $\mathrm{N}$ containing species determined from $\mathrm{N}$ K-edge X-ray absorption spectroscopy. ${ }^{23}$ Initially, the sample was exposed to $\mathrm{NO}_{2}$ at $25^{\circ} \mathrm{C}$, the gases were pumped out, and the sample was heated to the indicated temperatures.

after $\mathrm{NO}_{2}$ exposure, twice the amount seen over the dehydrated sample. ${ }^{23 \mathrm{a}}$

The unit cell changes as a function of temperature during the heating process are shown in Figure 5a. The unit cell parameters of the hydrated sample before and after $\mathrm{NO}_{2}$ adsorption/reaction were 24.607 and $24.502 \AA$, respectively. The contraction due to the $\mathrm{NO}_{2}$ dosing over the hydrated sample was $\sim 0.10 \AA$. Compared to the pure dehydrated BaY sample ( $a$ $=24.848 \AA$ ), the net contraction with both water and $\mathrm{NO}_{x}$ molecules inside the zeolite cages was around $0.34 \AA$. This contraction was larger than the changes for samples containing either water $(0.24 \AA)$ or $\mathrm{NO}_{x}(0.16 \AA)$ alone, indicating that the contraction of the hydrated $\mathrm{BaY}$ unit cell was enhanced by exposure to $\mathrm{NO}_{2}$. This phenomenon might be a consequence of the reaction $\mathrm{H}_{2} \mathrm{O}+\mathrm{NO}_{2} \rightarrow \mathrm{NO}_{3}{ }^{-}+\mathrm{H}^{+}$. Assuming that the interactions between $\mathrm{NO}_{3}{ }^{-}$and the framework and/or $\mathrm{Ba}^{2+}$ cations were stronger than with either water or $\mathrm{NO}_{2}$ molecules, then the unit cell would contract more after the formation of a large amount of $\mathrm{NO}_{3}{ }^{-}$species. This hypothesis is supported by the results of time-resolved XRD and X-ray adsorption spectroscopy shown in Figure 5. ${ }^{23}$

In Figure $5 \mathrm{~b}, \mathrm{NO}_{3}{ }^{-}$formation is observed at temperatures between 25 and $\sim 85^{\circ} \mathrm{C}$ and the unit cell of the zeolite (Figure 5a) contracts. Such behavior was not seen for the dehydrated BaY sample exposed to $\mathrm{NO}_{2}$ (Figure 4), indicating again the existence of a structural change as a consequence of the chemical reaction of $\mathrm{NO}_{2}$ with $\mathrm{H}_{2} \mathrm{O}$. The results from $\mathrm{N} \mathrm{K}$-edge XANES experiments ${ }^{23}$ showed that the relative amount of adsorbed $\mathrm{NO}_{3}{ }^{-}$ species decreased when heating at temperatures above $75^{\circ} \mathrm{C}$, 
the unit cell started to expand quickly till the temperature reached $240{ }^{\circ} \mathrm{C}$, and then a small negative thermal expansion was observed.

This is the first time that a zeolite unit cell contraction has been reported as a consequence of the adsorption of $\mathrm{NO}_{x}$ species or a chemical reaction inside the zeolite cages. The strong interaction between the $\mathrm{NO}_{x}$ groups and the cations or zeolite framework provides the forces necessary to shrink the unit cell. One can expect that these forces will not be unique for the $\mathrm{NO}_{2}-$ $\mathrm{BaY}$ or $\left\{\mathrm{NO}_{2}, \mathrm{H}_{2} \mathrm{O}\right\}-\mathrm{BaY}$ systems, and the phenomena observed in the present study will be seen when $\mathrm{NO}_{2}$ interacts with other zeolites. There are, however, clear indications that $\mathrm{NO}_{2}$ interacts better with $\mathrm{BaY}$ than with $\mathrm{NaY}$ zeolite. ${ }^{15,23 \mathrm{a}}$ The good performance of the $\mathrm{BaY}$ zeolite for the nonthermal plasma assisted catalytic reduction of $\mathrm{NO}_{x}$ species ${ }^{15}$ could be a consequence of strong interaction of the adsorbents with $\mathrm{Ba}$ cations, which eventually produces a shift in the position of the cations and a decrease in the zeolite unit cell. ${ }^{23 a}$

\section{Conclusions}

The results of in situ time-resolved X-ray diffraction indicate that the pure dehydrated $\mathrm{BaY}$ faujasite has a negative thermal expansion coefficient. A complex contraction/expansion behavior for the unit cell of the $\mathrm{BaY}$ faujasite zeolite was observed after interaction with water, $\mathrm{NO}_{2}$, or a $\left\{\mathrm{NO}_{2}, \mathrm{H}_{2} \mathrm{O}\right\}$ mixture. The unit cell for $\mathrm{BaY}$ samples containing either water or $\mathrm{NO}_{x}$ species alone was substantially smaller than that of the dehydrated $\mathrm{BaY}$ faujasite. A strong interaction between the framework and water or $\mathrm{NO}_{x}$ groups provided the force necessary to contract the unit cell. With bound water or $\mathrm{NO}_{x}$ molecules, the refined unit cell parameter was observed to increase as a function of temperature due to desorption of the adsorbates. The interaction between $\mathrm{NO}_{3}{ }^{-}$species and the zeolite framework or Ba cations was stronger than those of water and $\mathrm{NO}_{2}$, and the unit cell was observed to decrease substantially during the formation of nitrate $\left(\mathrm{H}_{2} \mathrm{O}+\mathrm{NO}_{2} \rightarrow \mathrm{NO}_{3}{ }^{-}+\mathrm{H}^{+}\right)$. This illustrates how a chemical reaction inside the cages can induce a contraction in the unit cell of a zeolite.

Acknowledgment. We thank Dr. Ja Hun Kwak (Pacific Northwestern National Laboratory) for the preparation of the BaY samples. The research carried out at the Chemistry Department of Brookhaven National Laboratory was financed through contract DE-AC02-98CH10086 with the U.S. Department of Energy (Division of Chemical Sciences). The NSLS is supported by the Divisions of Materials and Chemical Sciences of DOE. The Pacific Northwest National Laboratory is operated for the U.S. DOE by Battelle Memorial Institute under Contract No. DE-AC067RLO1831.

\section{References and Notes}

(1) Moïse, J. C.; Bellat, J. P.; Méthivier, A. Microporous Mesoporous Mater. 2001, 43, 91.

(2) Ståhl, K.; Hanson, J. J. Appl. Crystallogr. 1994, 27, 543.

(3) Koller, H.; Burger, B.; Schneider, A. M.; Engelhardt, G.; Weitkamp, J.; Microporous Mater. 1995, 5, 219.

(4) Marra, G. L.; Fitch, A. N.; Zecchina, A.; Ricchiardi, G.; Salvalaggio, M.; Bordiga, S.; Lamberti, C. J. Phys. Chem. B 1997, 101, 10653.

(5) Norby, P.; Poshni, F. I.; Gualtieri, A. F.; Hanson, J. C.; Grey, C. P. J. Phys. Chem. B 1998, 102, 839.

(6) Sani, A.; Cruciani, G.; Gualtieri, A. F. Phys. Chem. Miner. 2002, 29,351

(7) Kirschhock, C.; Fuess, H. Zeolite 1996, 17, 381.

(8) (a) Lee, Y., Vogt, T.; Hriljac, J. A.; Parise, J. B.; Hanson, J. C.; Kim, S. J.; Nature, 2002, 420, 485. (b) Baur, W. H. Nature Mater. 2003, $2(1), 17$.

(9) Marinkovic, B. A.; Jardim, P. M.; Saavedra, A.; Lau, L. Y.; Baehtz, C.; de Avillez, R. R.; Rizzo, F. Microporous Mesoporous Mater. 2004, 71, 117.

(10) Reisner, B. A.; Lee, Y.; Hanson, J. C.; Jones, G. A.; Parise, J. B.; Corbin, D. R.; Toby, B. H.; Freitag, A.; Larese, J. Z.; Kahlenberg, V. Chem. Commun. 2000, 22, 2221 .

(11) Colantuono, A.; Dal Vecchio, S.; Mascolo, G.; Pansini, M Thermochim. Acta 1997, 296, 59 .

(12) Lightfoot, P.; Woodcock, D. A.; Maple, M. J.; Villaescusa, L. A. Wright, P. A. J. Mater. Chem. 2001, 11, 212.

(13) Sleight, A. W. Inorg. Chem. 1998, 37, 2854.

(14) (a) Wang, X.; Spivey, J. J.; Lamb, H. H. Appl. Catal. B, in press. (b) Wang, X.; Sigman, S.; Spivey, J. J.; Lamb, H. H. Catal. Today, in press.

(15) (a) Kwak, J. H.; Szanyi, J.; Peden, C. H. F. J. Catal. 2003, 220 , 291. (b) Kwak, J. H.; Szanyi, J.; Peden, C. H. F. Catal. Today 2004, 89, 135. (c) Szanyi, J.; Kwak, J. H.; Peden, C. H. F. J. Phys. Chem. B 2004, 108,3746

(16) Grey, C. P.; Poshni, F. I.; Gualtieri, A. F.; Norby, P.; Hanson, J. C.; Corbin, D. R. J. Am. Chem. Soc. 1997, 119, 1981.

(17) (a) Wang, X.; Hanson, J. C.; Liu, G.; Rodriguez, J. A.; IglesiasJuez, A.; Fernández-García, M. J. Chem. Phys. 2004, 121 (11), 5434. (b) Wang, X.; Hanson, J. C.; Frenkel, A. I.; Kim, J.-Y.; Rodriguez, J. A. J. Phys. Chem. B 2004, 108 (36), 13667. (c) Chupas, P. J.; Grey, C. P.; Hanson, J. C.; Kim, J.-Y.; Rodriguez, J. A.; Qiu, X.; Billinge, S. J.; Lee, P. L. Commun. Powder Diffraction Newsletter 2003, 29, 24.

(18) Hammersely, A. P.; Svensson, S. O.; Thompson, A. Nucl. Instrum Methods Phys. Res. 1994, 346, 321.

(19) IDL, Version 5.5. Research System, Inc., 2002.

(20) (a) Larson, A. C.; von Dreele, R. B. GSAS General Structure Analysis System. Report LAUR 86-748; Los Alamos National Laboratory: Los Alamos, NM, 1995. (b) Reitveld, A. M. J. Appl. Crystallogr. 1969, 2 , 65. (c) Toby, B. H. J. Appl. Crystallogr. 2001, 34, 210.

(21) Grey, C. P.; Poshni, F. I.; Gualtieri, A. F.; Norby, P.; Hanson, J. C.; Corbin, D. R. J. Am. Chem. Soc. 1997, 119, 1981.

(22) Wang, X.; Hanson, J. C. Langmuir, submitted for publication.

(23) (a) Wang, X.; Hanson, J. C.; Kwak, J. H.; Szanyi, J.; Rodriguez, J. A. To be published. (b) The results of X-ray absorption spectra at the $\mathrm{N}$ K-edge showed the presence of $\mathrm{NO}_{3}{ }^{-}$(dominant species), $\mathrm{NO}_{2}$, and $\mathrm{NO}^{+}$ inside the cages of the dehydrated BaY sample. For the hydrated BaY samples, only $\mathrm{NO}_{2}$ and $\mathrm{NO}_{3}{ }^{-}$(dominant species) were detected. Initially, the sample was exposed to $\mathrm{NO}_{2}$ at $25^{\circ} \mathrm{C}$, the gases were pumped out, and the sample was heated to the elevated temperatures. 